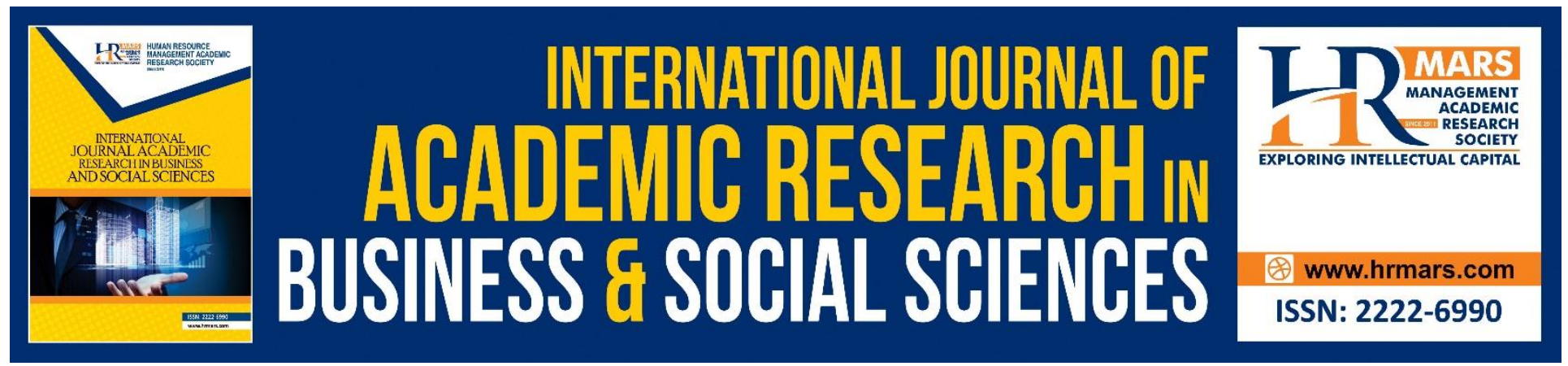

\title{
Insurance Coverage amongst Low Income Households (B40) in Perak
}

Syazwani Mohd Bakri, Norimah Rambeli @ Ramli \& Norazrin Amirah Sulaiman

To Link this Article: http://dx.doi.org/10.6007/IJARBSS/v8-i11/5350

DOI: $10.6007 /$ IJARBSS/v8-i11/5350

Received: 07 Nov 2018, Revised: 28 Nov 2018, Accepted: 30 Nov 2018

Published Online: 11 Dec 2018

In-Text Citation: (Bakri, Ramli, \& Sulaiman, 2018)

To Cite this Article: Bakri, S. M., Ramli, N. R. @, \& Sulaiman, N. A. (2018). Insurance Coverage amongst Low Income Households (B40) in Perak. International Journal of Academic Research in Business and Social Sciences, 8(11), 1733-1746.

\section{Copyright: (c) 2018 The Author(s)}

Published by Human Resource Management Academic Research Society (www.hrmars.com)

This article is published under the Creative Commons Attribution (CC BY 4.0) license. Anyone may reproduce, distribute, translate and create derivative works of this article (for both commercial and non-commercial purposes), subject to full attribution to the original publication and authors. The full terms of this license may be seen

at: $\underline{\text { http://creativecommons.org/licences/by/4.0/legalcode }}$

Vol. 8, No. 11, 2018, Pg. 1733- 1746

http://hrmars.com/index.php/pages/detail/IJARBSS

JOURNAL HOMEPAGE

Full Terms \& Conditions of access and use can be found at http://hrmars.com/index.php/pages/detail/publication-ethics 


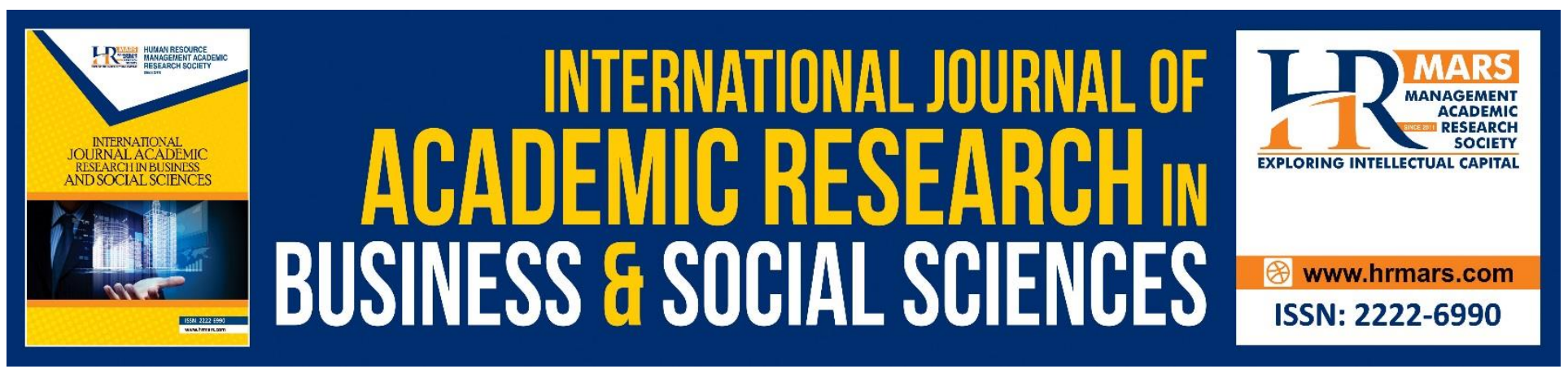

\title{
Insurance Coverage amongst Low Income Households (B40) in Perak
}

\section{Syazwani Mohd Bakri, Norimah Rambeli @ Ramli \& Norazrin Amirah Sulaiman}

Economic Department, Faculty of Management and Economics, Sultan Idris Education University,

Tanjong Malim, Perak.

Email: syazwanibakrirokiah@yahoo.com

\begin{abstract}
The focus point of this very study is to identify the socio-demographic and economic factors affecting insurance coverage amongst the lowest income households (B40) in Perak. The Logit Model and Ordinary Least Square Model were applied in achieving the objectives of the study. As such, based on the results of Model 1, the findings show that gender, marital status, residential location, type of employment, savings and loans are significant features which give effect to the probability of insurance coverage ownership (Logit Model). Meanwhile, Model 2 shows that the level of education solely is crucial in affecting the total insurance expenditure (OLS Model). Furthermore, Model 3 suggests that only age and loans are the important influence to the probability of having an insurance (Logit Model). Finally, Model 4 exhibits that the factors of race, residential location, education level, type of employment sector, number of dependents, income, savings and loans are the essential influence to estimate the affordable amount of insurance expenditure (Model OLS). On average, the lowest-income households (B40) in Perak who have the most insurance procure monthly insurance expenses ranging from RM101 to RM200, while the lowest-income households (B40) who do not have insurance but hold the want to have one are most willing to obtain insurance expenses between RM51 to RM100. Hence, this indicates that the lowest income households (B40) in Perak are in fact interested in owning insurance but due to several factors or constraints; these have become the impinging reasons for their inability to pay the insurance premium monthly. To treat this, BNM should increase the participation in the ownership amongst Low Income Households (B40) by a reduction in distribution costs, simplification of the design and delivery of products as well as assurance of meaningful protection to policy holders.
\end{abstract}

Keywords: Insurance coverage, Lowest income households (B40), Logit Model, OLS Model 


\section{Introduction}

Presently, most people have insurance to guarantee their safety in terms of losses and financial stability particularly in the event of undesirable things. As a matter of fact, insurance is the expenditure for life expectancy which made continuously and consistently to manage the risk of unexpected losses such as premature death, accident, health and medical costs during the life cycle. Nowadays, insurance is important to all communities' daily lives as they are exposed to various risks which cannot be predicted. Insurance expenses is also known as life expectancy spending consisting of life insurance, health and medical insurance, personal accident insurance and family insurance too. There are four types of insurance expenses representing the lifespan expenses wherein life expectancy is related to the expenditure to be incurred in the event of an accident, such as a family member's death and illness. Therefore, it is recommended that each households should have insurance premium especially the lowest income household.

There are several classification of households in Perak (Malaysia) distinguished by their monthly average income of households; the first one is the highest households income 20\% (T20), the middle households income 40\% (M40) and the lowest households income 40\% (B40). According to the Survey of Income and Expenditure of Households (Jabatan Perangkaan Malaysia, 2017), the highest households income 20\% (T20) indicates the households that earn RM6,980 per month and above. While the middle households income 40\% (M40) refers to households with average monthly income between RM3,460 to RM6,980 per month. Next, the lowest households income 40\% (B40) denotes the households earning below RM3,460 per month. In this manner, the lowest income households' category (B40) has become the concern of the Malaysian government to improve living standards and reduce the income gap between the B40 with other income groups. Henceforth, the purpose of this article is to build a model of insurance coverage amongst the lowest income households (B40) in Perak.

\section{Study Background}

The average household monthly income earned by the lowest households income (B40) is only RM2,848 compared to Malaysia's average household monthly income, which is RM6,958 for the year 2016. This shows that there is a large income gap between the lowest income households (B40) and Malaysia's average household income. Apart from that, the saving tendency for the lowest income households (B40) is at low level which in turn can affect their financial position to create face daily expenditure and expectation of external expenditure or emergency. Income that they achieve is barely enough for their daily and monthly expenditure. The effect that they will encounter is expenditure problem exceeding the income when they dealing with contingency like medical cost or personal accident as the medical cost for health care in hospital mostly increasing from year to year since many medical devices and medicines are imported from overseas (Norliza, 2015). Consequently, this group tends to obtain for loan as the expenses has surpassed income achieved. Likewise, the household financial position for the lowest income households (B40) in the year 2014 had increasingly concerned with high debt level in supporting daily and contingency expenses (Nor Hamizah, 2016). 
Based on the finance situation of lowest income households (B40) with regards to their income, fund, loan and expenses, it clearly shows that this group is vulnerable to economic shock and financial instability. Accordingly, the safety measurement that supposed to be done by B40 group is to own a reserve or insurance in reducing loss risk when facing economic shock or contingency expenses such as premature death, old age, health decline, natural disaster and so forth. As a result, this study will identify the insurance demand level among B40 group pertaining to their financial challenges. Apart from that, this study is also intended to identify the influence factor for insurance ownership, total insurance spending, wish prospect to have insurance and total estimation of insurance spending that the B40 group ready to procure. This much said study is also aimed to identify the estimation of monthly insurance spending that can be allotted by B40 group.

\section{Literature Review}

There are numerous studies being made that suggest socio-demographic factors as independent variables in determining the demand for workers in Malaysia and abroad. According to Peprah, Koomson \& Forson (2017), the demographic factor is the factor that really stands out in the local demand. Among the demographic aspects that are applied as independent variables; gender, marital status, age, race, place of residence, education level, occupation and so forth. For this, demographic factors consisted of continuous and non-continuous data. Demographic factors, for instance; age is categorized as continuous data while the non-continuous data is called as dummy variables, for example; gender, marital status, race, and location of residence. Whereas, social factors are sorted by way of education level, experience, type of work and number of dependents.

While Loke and Goh (2012) determined that the socio-demographic and economic factors affecting the demand for life insurance by means of questionnaire, it is discovered that factors related to gender was not significant. Via the count-hurdle model data used to analyze the factors affecting life insurance ownership among occupations in the state, it is found out that more men than women have insurance. However, more women are allocated expenses for life insurance than men. Instead, the probability to purchase health insurance in Arpah (2012) attained that women buy more health insurance than men. Peprah, Koomson and Forson (2017) applying binary logit estimation on data Ghana Living Standards Survey (glss-6) found that women have more insurance than men because women are more exposed to risk to be deterred than men. This is also due to the reason that women have a level of awareness to the importance of higher insurance than men although most household heads are men.

Loke \& Goh (2012) stated that $50 \%$ of respondents who are not married have insurance compared to $65 \%$ of the respondents who are married. This proves that those who have been married possess more interest in life than those who are single for the reason that respondents who are married have dependents to be taken care if unwanted situation happen. Peprah, Koomson and Forson (2017) asserted in a study whether poverty, employment status and demographic characteristics influence the demand for workers in Ghana in 2012 and 2013 found that the demand is higher among amongst those who were married than the unmarried. Such situation occurred as those who are married are confident that the workers could secure the future of their family 
members. Moreover, the responsibility for those who have been married is bigger than a supporting member of the family consisting of his wife and children than those who are not married.

According to BBrighetti, Lucarelli and Marinelli (2014), age affects the demand for life insurance and health insurance positively because older households need protection and financial stability when their family is growing. Similarly, Weni and Marhanum (2012) found that age was positively related to the request of the family takaful insurance in Malaysia. This positive relationship is further supported by several studies including Showsers and Shotick (1994), Baek and DeVaney (2005). Nonetheless, the opposite is also true in Arpah (2012) that the age-related non-linearly with the purchase of insurance in predicting the probability of individuals buying health insurance for both groups of individuals; paid and unpaid.

Additionally, Arpah (2012) discovered that the probability to buy health insurance is higher among the Chinese in Malaysia. According to Jones (2012), it is found that Chinese people are more interested to procure health insurance in 1996. However, all the nation of Malays, Chinese, Indians and other indigenous people have become significant in influencing the decisions of health insurance ownership in 2006 using bivariate Logit model and moral hazard theory. Afterwards, study on the demand for life insurance in Sri Lanka from the religious aspect as established by Arun, Bendig and Arun (2012) shows that heads of households who are Hindus and Buddhists own less probability to have and to pay life insurance premiums compared to heads of household who are Christians. This is due to the cause that a Hindu household is comprised of Tamils who have a high risk Dodger attitude; the attitude of low confidence and low access to the insurance market which subsequently render them less participation in any insurance scheme.

Furthermore, Tan et al. (2014) employs regression model Cragg's two-part and found that the Malay community living in the metropolitan area of more than $1.30 \%$ have life insurance by making monthly insurance expense of RM31.63 compared to households in the eastern region. Households in the metropolitan area not only spent a total of RM25.01 per month for life insurance expenses. Plus, the Chinese community in the peninsula living in metropolitan areas also have life insurance of $11.15 \%$ compared to $10.70 \%$ of those not living in the metropolitan area and each spent a total of RM20.27 and RM18.56 per month for life insurance expenses. Also, holders of life insurance policies of the Chinese community in the metropolitan area spent a total of RM31.43 per month than those who live in eastern Malaysia. In addition, those living in urban areas have insurance $3.33 \%$ more than in rural areas. For the people of India, there was no significant relationship between the life insurance shopping with residential areas. The results of the study by Lee, Kwon and Chung (2010) displayed that the people living in small towns and rural areas in Korea bought more insurance coverage of deposits compared to the occupation living in metropolitan cities. This is due to the factor of individual experience and exposure in the vicinity of residential areas that affect the demand for insurance. Besides, people living in large cities usually have insurance coverage provided by the employer or the company they work for. 
Following to this, Arpah (2012) learnt that the probability of buying health insurance is higher among those with higher education using regression analysis logistics and Two Stage Heckman estimator. Not forget to be mentioned, Brighetti, Lucarelli and Marinelli (2014) obtained a finding that the most life insurance and health insurance are for those who have a tertiary level of education which gives significant positive correlation between the demand for workers with tertiary education. These findings are supported as well by several studies that achieved the same results as Burnett and Palmer (1984), Browne and Kim (1993), Gandolfi and Miners (1996), Baek and DeVaney (2005) and Li et al. (2007). Nevertheless, there are also some studies found different results such as Anderson and Nevin (1975) and Goldsmith (1983). Ahmed et al. (2016) also found that education level was significantly associated with a willingness to pay for health insurance among informal workers in Bangladesh. Based on studies made by Jones (2012), in comparing the two years of 1996 and 2006, and using data from the National Health and Morbidity Survey (NHMS) in Malaysia from 1996 to 2006; it is disclosed that individuals with higher education have private health insurance in 2006 than in 1996. This is because public exposure of workers in the 90's was less than in early 2000.

Moreover, Peprah, Koomson and Forson (2017) submitted that the salaried employees remained as higher demand compared to self-employed workers. The results of this study differed slightly from a study conducted by Arpah (2012) that government employees have a high probability to buy health insurance when compared with employees who are not working in the government sector. This is owed to their stable earning income and capability to pay a monthly insurance policy. Another than that, the research done by Brighetti, Lucarelli and Marinelli (2014) indicated the workers have a positive relationship with the employment situation (working condition) and the results of this study were also supported by Beck and DeVaney (2005), Li et al. (2007), Duker (1969), Fitzgerald (1987), Koeniger (2004) and Liebenberg et al. (2012). In addition, there were also different studies such as Anderson and Nevin (1975) and Goldsmith (1983).

Besides, Weni and Marhanum (2012) found that the ratio of dependents to workers affect the demand positively too. This shows that the greater of the dependency ratio; means that the demand for insurance shall increase. Similar results were also obtained by Brighetti, Lucarelli and Marinelli (2014), the demand for insurance (life and health) is influenced by the number of dependents in a positive way. More number of dependents causing an increase in demand for workers. This finding is supported by several studies such as Fortune (1973); Campbell (1980); Beenstock, Dickinson, and Khajuria (1986); Lewis (1989); Truett and Truett (1990); Brown and Kim (1993); Burnett and Palmer (1984), Showsers and Shotick (1994), Outreville (1996); Beck and Webb (2003); Lenten and Rulli (2006); Li et al. (2007); and Liebenberg et al. (2012). Next, Arun, Bendig and Arun (2012) in identifying patterns of investment in life insurance, micro demands of insurance, availability of insurance, and determination of the participation of low-income group life insurance microstructure which is one of the products mikroinsurans in Sri Lanka found that participation in the life insurance and micro related was positive with a high number of dependents comprising of young people.

Furthermore, Arpah (2012); by using the data obtained from the National Health and Morbidity Survey in Malaysia found that the probability of buying insurance is higher amongst 
individuals with high earning. Similarly, matching findings were obtained by Brighetti, Lucarelli and Marinelli (2014). The findings show that income has a positive relationship with the ownership of insurance (life and health) in Italy. Moreover, the finding is also corroborated with other studies, namely; Duker (1969), Cargill and Troxel (1979), Burnett and Palmer (1984), Babbel (1985), Beenstock et al. (1988), Lewis (1989), Truet and Truet (1990), Browne and kim (1993), Showsers and Shotick (1994), Gandolfi and Miners (1996), Outreville (1996), Browne et al. (2000), Beck and Webb (2003), Hwang and Gao (2003), Lim and Haberman (2004) and Ye et al. (2009).

Total expenses is essential in order to identify the impact of rising inflation, taxes and interest rates on the cost of insurance among households (Beck and Webb (2003). In addition, the total household expenditure actually affect household spending indirectly because one of the causes of poor households is the dislike own a child since the income earned can only cover the total expensesThis can be proved by research conducted by McCord (2011) for the project "Facilitating widespread Access to microinsurance Services" for the microfinance Center for Central and Eastern Europe, New Independent states and the microinsurance Center (LLC) on mikroinsurans products for lower income groups in some countries. Most households do not have insurance because of the amount of income earned just sufficient to meet major expenses such as expenses on food and utilities. This shows that an increase in household spending caused a decline in demand for workers and the number of insurance expenses.

Subsequently, Kakar and Shukla (2010) realized that households which have insurance prefer to make savings in bank deposits. In addition, the level of confidence for households that have insurance on their finances in the future is higher than households that do not have insurance. Such situation happened may be due to their financial stability at the moment. There are also studies conducted which attained that there is no significant relationship between ownership insurance with financial wealth as financial wealth is the same item categorized as an asset insurance (Brighetti, Lucarelli and Marinelli, 2014). These findings are further supported by several studies including Duker (1969), Burnett and Palmer (1984), Showsers and Shotick (1994), Gandolfi and Miners (1996), Li et al. (2007), and Liebenberg et al. (2012).

Nonetheless, there are also studies which state the existence of a positive relationship between ownership insurance with financial wealth as confirmed by Duker (1969), Anderson and Nevin (1975) and Hau (2000). In addition, the survey carried out by Kakar and Shukla (2010) related to insurance expenses with loans found that there is an inverse relationship. Households that have a commitment to repay the loan have a low rate of insurance ownership. Thus, this means that households with debt are not interested to have insurance. Normally households that have bank loans, and education loans cause them to be incapable to provide a full range of insurance payments.

\section{SPECIFICATION MODEL}

Ensuing to this, this research has been conducted by applying model estimator based on Tan et al. (2014). According to a survey, analysis of factors affecting ownership and total insurance expenses for the B40 group is represented by ownership insurance, total monthly expenses of insurance, the 
desire to have insurance and the total estimated cost of insurance which can be made as the dependent variable. For independent variables, they are consisted of current income, gender, marital status, age, race, residential location, type of work, number of dependents, the monthly expenditure, savings and loans. Tan et al. (2014) states that the ownership and insurance expenses are influenced by socio-demographic and economic factors. However, this study differs from the study of Tan et al. (2014) in the aspect of the number of model, the type of data, focus groups, and different study areas. Moreover, Tan et al. (2014) only used two models; ownership model of insurance and the amount of insurance expenses while this study used four models. The first one is the ownership insurance model, total insurance expenses model, the desire to have insurance ownership model and the estimated total insurance expenses model that can be made. Next, the difference is that the types of data used in Tan et al. (2014) was the secondary cross-sectional data (Household Survey Data) whilst this study employs primary data to focus on the B40 group in Perak. Based on the basic model (2) and studies that have been conducted by Tan et al. (2014) as well as the function to estimate the model in this study are as follows;

$$
I N S_{i}=f(S D, E C O)
$$

$$
I N S_{i}=\alpha_{0}+\beta_{1} S D_{i}+\delta_{1} E C O_{i}+\varepsilon_{i}
$$

$$
\begin{aligned}
& \text { Model 1: Insurance Ownership (Logit Model) } \\
& \operatorname{Pr}\left(I_{1 i} S_{1}=1 \mid, M_{i} E_{i}, \text { SINGLE }_{i}, \text { MARRIED }_{i}, A G E_{i}, \text { MALAY }_{i}, \text { CHINESE }_{i},\right. \\
& \text { CITY }_{i}, \text { SPM }_{i}, \text { STPM / DIPLOMA }_{i}, \text { DEGREE }_{i}, \text { GOVERMENT }_{i}, \text { PRIVATE }_{i} \text {, } \\
& \text { SELF - EMPLOYED }{ }_{i}, \text { DEPENDENTS }_{i}, \ln \text { INCOME }_{i}, \ln \text { TEXPANSES }_{i} \text {, } \\
& \left.\ln S A V I N G_{i}, \ln L_{O A N}\right)=F\left(\alpha_{0}+\beta_{1} M_{i} A L E_{i}+\beta_{2} \operatorname{SINGLE}_{i}+\beta_{3} M_{A R R I E D_{i}}\right. \\
& +\beta_{4} A G E_{i}+\beta_{5} \text { MALAY }_{i}+\beta_{6} \text { CHINESE }_{i}+\beta_{7} \text { CITY }_{i}+\beta_{8} \text { SPM }_{i}+\beta_{9} S T P M / \\
& \text { DIPLOMA }_{i}+\beta_{10} \text { DEGREE }_{i}+\beta_{11} \text { GOVERMENT }_{i}+\beta_{12} \text { PRIVATE }_{i}+ \\
& \beta_{13} \text { SELF - EMPLOYED }{ }_{i}+\delta_{1} \ln \text { INCOME }_{i}+\delta_{2} \ln \text { TEXPENSES }_{i}+ \\
& \left.\delta_{3} \ln S A V I N G_{i}+\delta_{4} \ln L O A N_{i}+v_{i}\right) \\
& \text { Model 2: Total of monthly insurance spending (OLS Model) } \\
& I N S_{2 i}=\alpha_{0}+\beta_{1} M A L E_{i}+\beta_{2} \text { SINGLE }_{i}+\beta_{3} \text { MARRIED }_{i}+\beta_{4} A G E_{i}+\beta_{5} \text { MALAY }_{i} \\
& +\beta_{6} \text { CHINESE }_{i}+\beta_{7} \text { CITY }_{i}+\beta_{8} \text { SPM }_{i}+\beta_{9} \text { STPM / DIPLOMA }+ \\
& \beta_{10} \text { DEGREE }_{i}+\beta_{11} \text { GOVERMENT }_{i}+\beta_{12} \text { PRIVATE }_{i}+ \\
& \beta_{13} S E L F-E_{1 M P O Y E D_{i}}+\delta_{1} \ln \text { INCOME }_{i}+\delta_{2} \ln \text { TEXPENSES }_{i}+ \\
& \delta_{3} \ln \mathrm{SAVING}_{i}+\delta_{4} \ln L O A N_{i}+v_{i}
\end{aligned}
$$

Model 3: Desire to have Insurance Ownership (Logit Model) 
$\operatorname{Pr}\left(I_{N S} S_{3 i}=1 \mid, M_{i} E_{i}\right.$, SINGLE $_{i}$, MARRIED $_{i}, A G E_{i}$, MALAY $_{i}$, CHINESE $_{i}$, CITY $_{i}$, SPM $_{i}$, STPM / DIPLOMA $_{i}$, DEGREE $_{i}$, GOVERMENT $_{i}$, PRIVATE $_{i}$, $S E L F-E_{\text {EMPOYED }}$, DEPENDENTS $_{i}, \ln$ INCOME $_{i}, \ln$ TEXPANSES $_{i}$,

$\left.\ln S A V I N G_{i}, \ln L_{O A N}\right)=F\left(\alpha_{0}+\beta_{1} M_{i} A L E_{i}+\beta_{2}\right.$ SINGLE $_{i}+\beta_{3} M_{A R R I E D_{i}}$

$+\beta_{4} A G E_{i}+\beta_{5}$ MALAY $_{i}+\beta_{6}$ CHINESE $_{i}+\beta_{7}$ CITY $_{i}+\beta_{8}$ SPM $_{i}+\beta_{9} S T P M /$

DIPLOMA $_{i}+\beta_{10}$ DEGREE $_{i}+\beta_{11}$ GOVERMENT $_{i}+\beta_{12}$ PRIVATE $_{i}+$ $\beta_{13}$ SELF - EMPLOYED ${ }_{i}+\delta_{1} \ln$ INCOME $_{i}+\delta_{2} \ln$ TEXPENSES $_{i}+$ $\left.\delta_{3} \ln S A V I N G_{i}+\delta_{4} \ln L O A N_{i}+v_{i}\right)$

$$
\begin{aligned}
& \text { Model 4: Total Estimates Insurance Affordable can be Made (OLS Model) } \\
& \begin{aligned}
I_{4}= & \alpha_{0}+\beta_{1} \text { MALE }_{i}+\beta_{2} \text { SINGLE }_{i}+\beta_{3} \text { MARRIED }_{i}+\beta_{4} A G E_{i}+\beta_{5} M_{4} A L A Y_{i} \\
& +\beta_{6} \text { CHINESE }_{i}+\beta_{7} \text { CITY }_{i}+\beta_{8} \text { SPM }_{i}+\beta_{9} S T P M / \text { DIPLOMA }_{i}+ \\
& \beta_{10} \text { DEGREE }_{i}+\beta_{11} \text { GOVERMENT }_{i}+\beta_{12} \text { PRIVATE }_{i}+ \\
& \beta_{13} S E L F-\text { EMPLOYED }_{i}+\delta_{1} \ln \text { INCOME }_{i}+\delta_{2} \ln \text { TEXPENSES }_{i}+ \\
& \delta_{3} \ln S A V I N G_{i}+\delta_{4} \ln \text { LOAN }_{i}+v_{i}
\end{aligned}
\end{aligned}
$$

Where the terms for Model 1 (3), Model 2 (4), Model 3 (5) and Model 4 (6) are as follows;

$S D$

$E C O$

$\operatorname{Pr}$

$I N S_{1 i}$

$I N S_{2 i}$

$I_{N S} S_{3 i}$

$I N S_{4 i}$

LELAKI $_{i}$

$\operatorname{SINGLE}_{i}$

MARRIED

$A G E_{i}$

$M A L A Y_{i}$

CHINESE

CITY

\section{: Socio-demographic factors}

: Economic factors

: Probability

: Insurance ownership probability (1 for household that having an insurance, 0 for household with no insurance policy

: Total of monthly insurance spending

: Desire probability to have an insurance (1 for household that wish to have an insurance, 0 for household that have no desire for an insurance

: Total estimation of insurance spending that can be done per month

: Gender ( 1 for the head of the male household, 0 for the head of the female household)

: Marital Status ( 1 for the head of single household, 0 to other)

: Marital Status (1 for the head of household was married, 0 for others)

: Age

: Race (1 for Malay household, 0 to other other)

: Race (1 for Chinese household, 0 to other other)

: Residence Location (1 for household that stay in area town, 0 for household stay in rural areas) 
INTERNATIONAL JOURNAL OF ACADEMIC RESEARCH IN BUSINESS AND SOCIAL SCIENCES

Vol. 8, No. 11, Nov, 2018, E-ISSN: 2222-6990 @ 2018 HRMARS

\begin{tabular}{|c|c|}
\hline$S P M_{i}$ & $\begin{array}{l}\text { : Education Level ( } 1 \text { for head of household owns } \\
\text { the secondary school level, } 0 \text { for others) }\end{array}$ \\
\hline STPM/DIPLOMA & $\begin{array}{l}\text { : Education Level ( } 1 \text { for head of household owns } \\
\text { high school education or diploma level, } 0 \text { for others) }\end{array}$ \\
\hline$D E G R E E_{i}$ & $\begin{array}{l}\text { : Education Level ( } 1 \text { for head of household owns degree, } 0 \text { for } \\
\text { others) }\end{array}$ \\
\hline GOVERMENT & $\begin{array}{l}\text { : Job ( } 1 \text { for head of household working in government sector , } 0 \\
\text { for others) }\end{array}$ \\
\hline PRIVATE $_{i}$ & $\begin{array}{l}\text { : Job ( } 1 \text { for head of household working in private sector, } 0 \text { for } \\
\text { others) }\end{array}$ \\
\hline SELF-EMPLOYED & $\begin{array}{l}\text { : Job ( } 1 \text { for head of household self-employed, } 0 \text { to } \\
\text { other) }\end{array}$ \\
\hline DEPENDENTS & : Number of dependents \\
\hline $\operatorname{InINCOME} E_{i}$ & : Household current monthly income \\
\hline In EXPANSES & : Household total monthly expenses \\
\hline In SAVING $i$ & : Household total monthly saving \\
\hline In $L O A N_{i}$ & : Number of monthly loan repayment \\
\hline$a_{0}$ & : Parameters for constant variable \\
\hline$\beta_{1-8}$ & : Parameters for socio-demographic variables \\
\hline$\delta_{1-4}$ & : Parameters for economic variables \\
\hline$v_{i}$ & : Error term \\
\hline$i$ & : Primary data \\
\hline
\end{tabular}

As mentioned, there are four models in this study based on the study by Tan et al (2014) to identify the demand for insurance among B40 group. The difference of this models are different by dependent variables. While the independent variables for all four models are the same, such as sociodemographic factors (gender, marital status, age, race, place of residence, education level, occupation and number of dependents) and economic factors (current income, expenses, savings and loans).

The first model of equation (3) using the Logit model built with the aim to determine the socio-demographic and economic factors that influence the probability of insurance ownership among the B40 group. The dependent variable is the probability of insurance ownership, that is, whether the B40 group has an insurance policy or otherwise. This variable is a binary variable coded with " 1 " for the households that have insurance while " 0 " is households that do not have insurance. Hence, in this model, it is shown the factors that affect households which have insurance and factors that affect households for not having insurance.

Equation (4) is the second model built with the aim to determine the socio-demographic and economic factors affecting the total insurance expenses per month. This model is a continuance of the first model. The dependent variable in the model is the total spending for the insurance premiums per month. In this manner, Ordinary Least Squares (OLS) Method is to be used in the analysis.

Next, equation (5) is the third model built with the aim to determine the socio-demographic and economic factors that affect the B40 group to have insurance. This model is also a continuance 
of the first model when there are households not owning insurance but wish to have one. This model also uses a Logit model to analyse the relationship between independent variables and dependent variables. The dependent variable for this model is the probability of a desire to have an insurance. Then the variable is coded with " 1 " for the households who want to have insurance, while " 0 " is for households that do not want to have insurance. The results of this model can suggest the factors affecting the households who want insurance and the causes that affect the household to not having insurance.

Plus, Equation (6) is the fourth model which is a continuation of the first and third models. This model exists because there are households who do not have insurance but wish to have insurance. The purpose of this model is to determine the factors that affect the amount of budget spending a month for insurance that can be made by households. Ordinary Least Squares Method is to be used in the analysis.

\section{CONCLUSION}

Based on Model 1, it clearly shows that gender factor (Male), marital status (Single and Married), residence location (City), employment sector type (self-employed), saving and loan are significant or important influence for the probability of insurance ownership (Logit Model). Model 2, on the other hand, shows that only education level factor (STPM / Diploma and Degree and above) is the important influence for the total insurance spending (OLS Model). Afterwards, Model 3 shows that only age and loan factors influence the probability of desire to have an insurance (Logit Model). Finally, Model 4 shows that race factor (Chinese), residence location (City), education level (STPM / Diploma), type of employment sector (Government Sector and Self-employed), the number of dependents, income, saving and loan influence the istimated total insurance spending that can be made (OLS Model). The average monthly insurance spending for households B40 group in Perak is between RM101 to RM200, while the B40 group who do not own insurance but wish to have insurance willing to pay insurance spending between RM51 to RM100.

What is more, there are few shocking findings being made in this study in which the income factor is not the main factor for B40 group in Perak to have an insurance except for Model 4. Nevertheless, the loan factor gives big implication in influencing household insurance ownership because of the significant number of loan factor is found in all three Model at the Model 1, Model 3 and Model 4. This proves that loan is a major factor in having an insurance for B40 group in Malaysia. Apart from that, educational factors display that household that own Diploma / STPM level tends to have an insurance compared to those who have SPM, degree and above. This circumstance happened because household that owns STPM / Diploma level possesses awareness and interest for insurance coverage compared to those who own secondary school education level below. Despite of the fact, for those who own degree education level and above, there is a reduced amount of those who have an insurance because they own other method methods should they be confronted with unforeseen circumstances.

As established, the government should find alternative way to attract the B40 group to have insurance. For example, government ought to put up special fund to insurers that will be entrusted 
to produce friendly insurance product to the B40 group. In this lieu, it can reduce the total payment for the premium insurance per month by way of the injection from government. As a result of this implementation, it can effectively nurture household the concept of saving and investment. Indirectly, this can ensure and take care of B40 group's household welfare in the case when they face contingency condition especially accident and death. This cooperation not just brings advantage to B40 group but can also increase further investment for insurance sector in Malaysia.

\section{Acknowledgment}

We would like to thank the people involved in making this article published especially towards Dr. Norimah Binti Ramli @ Rambeli as supervisor in this research. An appreciation is also given to Kementerian Pengajian Tinggi which has provided us the sponsorship for this research under the grant FRGS Top Down (2016-0215-106-41). Not to be put behind, thank you to the faculty and university for trusting us. Finally, thanks to our family and friends who have supported us all this time.

\section{Corresponding Author}

I am Syazwani binti Mohd Bakri, a post-graduate student in economic development from the Sultan Idris Education University, Tanjong Malim, Perak. Email: syazwanibakrirokiah@yahoo.com

\section{References}

Ahmed, S., Hoque, M. E., Sarker, A. R., Sultana, M., Islam, Z., Gazi, R., \& Khan, J. A. (2016).Willingnessto-pay for community-based health insurance among informal Workers in Urban Bangladesh. PloS one, 11(2), e0148211.

Anderson, D. R., \& Nevin, J. R. (1975). Determinants of young marrieds' life insurance purchasing behavior: An empirical investigation. Journal of Risk and Insurance, 375-387.

Arpah, A. B. (2012). The Individual Demand for Private Health Insurance in Malaysia (Doctoraldissertation, Universiti Utara Malaysia).

Arun, T., Bendig, M., \& Arun, S. (2012). Bequest motives and determinants of micro life insurance in Sri Lanka. World Development, 40(8), 1700-1711.

Babbel, D. F. (1985). The price elasticity of demand for whole life insurance. The Journal of Finance, 40(1), 225-239.

Baek, E., \& DeVaney, S. A. (2005). Human capital, bequest motives, risk, and the purchase of life insurance. Journal of Personal Finance, 4(2), 62.

Beenstock, M., Dickinson, G., \& Khajuria, S. (1986). The determination of life premiums: An international cross-section analysis 1970-1981. Insurance: Mathematics and Economics, 5(4), 261-270.

Brighetti, G., Lucarelli, C., \& Marinelli, N. (2014). Do emotions affect insurance demand?. Review of Behavioral Finance, 6(2), 136-154.

Browne, M. J., \& Kim, K. (1993). An international analysis of life insurance demand. Journal of Risk and Insurance, 616-634.

Browne, M. J., Chung, J., \& Frees, E. W. (2000). International property-liability insurance consumption. Journal of Risk and Insurance, 73-90. 
INTERNATIONAL JOURNAL OF ACADEMIC RESEARCH IN BUSINESS AND SOCIAL SCIENCES

Vol. 8, No. 11, Nov, 2018, E-ISSN: 2222-6990 @ 2018 HRMARS

Burnett, J. J., \& Palmer, B. A. (1984). Examining life insurance ownership through demographic and psychographic characteristics. Journal of risk and insurance, 453-467.

Campbell, R. A. (1980). The demand for life insurance: An application of the economics of uncertainty. The Journal of Finance, 35(5), 1155-1172.

Cargill, T. F., \& Troxel, T. E. (1979). Modeling life insurance savings: Some methodological issues. Journal of Risk and Insurance, 391-410.

Duker, J. M. (1969). Expenditures for life insurance among working-wife families. Journal of Risk and Insurance, 525-533.

Fitzgerald, J. (1987). The effects of social security on life insurance demand by married couples, Journal of Risk and Insurance, 54, 86-99.

Fortune, P. (1973). A theory of optimal life insurance: development and tests. The Journal of Finance 27 (3). 587-600.

Goldsmith, A. (1983). Household life cycle protection: human capital versus life insurance. Journal of Risk and Insurance 50(3). 33-44.

Gandolfi, A.S. and Miners, L. (1996). Gender-based differences in life insurance ownership. Journal of Risk and Insurance 63(4). 683-693.

Hau, A. (2000). Liquidity, estate liquidation, charitable motives, and life insurance demand by retired singles. Journal of Risk and Insurance, 67(1), 123-141.

Hwang, T. \& Gao, S. (2003). The determinants of the demand for life insurance in an emerging economy: The case of China. Managerial Finance 29(5/6). 82-97.

Jabatan Perangkaan Malaysia. (2017). Retrieved Disember, 2017, from Portal Rasmi Jabatan Perangkaan

Malaysia: https://www.dosm.gov.my/v1/index.php?r=column/cglossary2\&menu_id=eWd2VFdIZ2xpdz BmT2Y0aOpweDcwQT09

Jones, G. (2012). Moral hazard and the impact of private health insurance on the utilisation of health care in Malaysia. Jurnal Ekonomi Malaysia, 46(2), 159-175.

Kakar, P., \& Shukla, R. (2010). The determinants of demand for life insurance in an emerging economy-India. Margin: The Journal of Applied Economic Research, 4(1), 49-77.

Koeniger, W. (2004). Labor income risk and car insurance in the UK. The Geneva Papers on Risk and Insurance Theory, 29(1), 55-74.

Lee, S. J., Kwon, S. I., \& Chung, S. Y. (2010). Determinants of household demand for insurance the case of Korea. The Geneva Papers on Risk and Insurance-Issues and Practice, 35(1), S82-S91.

Lenten, L. J., \& Rulli, D. N. (2006). A time-series analysis of the demand for life insurance companies in Australia: An unobserved components approach. Australian Journal of Management, 31(1). 41-66.

Lewis, F. D. (1989). Dependents and the demand for life insurance. American Economic Review 79. 452-467.

Li, D., Moshirian, F., Nguyen, P., \& Wee, T. (2007). The demand for life insurance in OEC countries. Journal of Risk and Insurance, 74(3). 637-652.

Liebenberg, A.P., Carson, J.M. \& Dumm, R.E. (2012). A dynamic analysis of the demand for life insurance. Journal of Risk and Insurance, 79(3). 619-644. 
Lim, C.C. \& Haberman, S. (2004). Modelling life insurance demand from a macroeconomic perspective: The Malaysian case. Research paper: The 8th International Congress on Insurance, Mathematics and Economics, Rome.

Loke, Y. J., \& Goh, Y. Y. (2012). Purchase decision of life insurance policies among Malaysians. International Journal of Social Science and Humanity, 2(5), 415-420.

McCord, M. J. (2011). Microinsurance product development for microfinance providers. From The Microlnsurance Centre.

Outreville, J.F. (1996). Inflation and saving through life insurance. Journal of Risk and Insurance, 63, 263-78.

Peprah, J. A., Koomson, I., \& Forson, R. (2017). Network for Socioeconomic Research and Advancement (NESRA). nesra/wp/17/001.

Showers, E.V. \& Shotick, A.J. (1994). The effects of household characteristics on demand for insurance: A Tobit analysis. Journal of Risk and Insurance, 61, 492-502.

Tan, A. K., Yen, S. T., Hasan, A. R., \& Muhamed, K. (2014). Demand for Life Insurance in Malaysia: An Ethnic Comparison Using Household Expenditure Survey Data. Asia-Pacific Journal of Risk and Insurance, 8(2), 179-204.

Truett, D.B. \& Truett, L.J. (1990). The demand for life insurance in Mexico and the United States: A comparative study. Journal of Risk and Insurance, 57, 321-328.

Weni Hawariyuni \& Marhanum Che Mohd Salleh. (2012). Modeling the demand for family and general takaful in Malaysia (a comparative study): ARDL approach to cointegration. Tazkia Islamic Finance and Business Review, 7 (1), 29-47.

Ye, D., Li, D., Chen, Z., Moshirian, F., \& Wee, T. (2009). Foreign participation in life insurance markets: Evidence from OECD countries. The Geneva Papers on Risk and Insurance-Issues and Practice, 34(3), 466-482. 